Fifth International Conference on Sustainable Construction Materials and

Technologies. http://www.claisse.info/Proceedings.htm

\title{
ULTRALIGHT MINERAL FOAMS FOR SUSTAINABLE INSULATION APPLICATIONS
}

\author{
Albrecht Gilka-Bötzow ${ }^{1}$, Sha Yang ${ }^{1}$ and Eduardus A.B. Koenders ${ }^{1}$ \\ ${ }^{1}$ Institute for Construction and Building Materials, TU Darmstadt, Franziska-Braun- \\ Straße 3, 64287 Darmstadt, Germany, gilka-boetzow@wib.tu.darmstadt.de
}

\begin{abstract}
The intention of the construction industry to contribute on cutting back on the global $\mathrm{CO} 2$ emissions is an issue that goes beyond any other question. A most important leverage remains on the reduction of energy consumption of buildings in operation. In this, high-performance insulation materials may play a major role. However, so far various insulation products widely used in buildings have come under discussion due to large uncertainties regarding their recyclability and, because of their poor performance when it comes to fire safety.

The Institute of Construction and Building Materials (WiB) at the TU Darmstadt is examining the performance of non-flammable and high-performance mineral-bounded foams for insulation purposes for many years. As partner in a joint research project for energy active factory construction called "Energy Transfer and Application factory ETA-Factory", a full-scale production hall was successfully built with a 30 to $40 \mathrm{~cm}$ thick insulating layer of mineralized foam applied, and an average density of $180 \mathrm{~kg} / \mathrm{m}^{3}$. For this, a mix design was developed at $\mathrm{WiB}$, in a semi-continuous production method for ultra-light and very robust foams in fresh condition, jointly with industrial partners. With this mineral foam based insulation layer, the whole building envelope of the ETA-factory was made of cement-based materials only.

As a consequence of this successful application of light mineral foam, research has been driven forward aiming at solving its most experienced weaknesses, viz. the not yet completely satisfying thermal conductivity $(\lambda \approx 0.065 \mathrm{~W} /(\mathrm{m} \cdot \mathrm{K}))$ and the relatively high chemical and drying shrinkage and, especially when regarding the associated crack formation. Significant progress has been made in both areas, resulting in mineral foams with densities of less than $100 \mathrm{~kg} / \mathrm{m}^{3}$ and with a thermal conductivity comparable to common insulation materials. In addition, in conjunction with a successful project application, a closed-loop recycling concept has be developed to achieve a significant capturing of $\mathrm{CO}_{2}$, whenever reusing recycled mineral foam in cement production facilities.
\end{abstract}

Keywords: mineral foams, non-flammable, high-performance mineral bounded foams. 


\section{INTRODUCTION}

It is possible to produce cement-based foams in a very wide density range (Table 1). Due to their good thermal insulation properties, high fire resistance and long durability, lightweight cementitious foams are recommended to achieve a successful energy efficiency in buildings. A large number of studies have already been carried out on the composition, physical properties and applications of foam concretes with a density ranging between $500 \mathrm{~kg} / \mathrm{m}^{3}$ and $600 \mathrm{~kg} / \mathrm{m}^{3}$ (Narayanan 2012, Othuman 2011, Panesar 2013, Ramamurthy 2009, Ranjani 2012). There is also some research published on very-lightweight foams with densities around $200 \mathrm{~kg} / \mathrm{m}^{3}$ (Akthar \& Evans 2010, Gilka-Bötzow 2016, Pott 2006) (see also Figure 1). While so far only little research has been done on the compositions and the properties of ultra-light mineral foam (ULMF) with densities lower than $160 \mathrm{~kg} / \mathrm{m}^{3}$ or even approaching $100 \mathrm{~kg} / \mathrm{m}^{3}$. This is probably due to their increased instability, as mineralized foams with bulk densities below $160 \mathrm{~kg} / \mathrm{m}^{3}$ no longer have a completely closed pore structure (Gilka-Bötzow et al. 2016). There is no research focussing on the mechanical and thermal properties of such low-density foam. Several researches reported that the thermal conductivity of ultra-lightweight foam concretes decrease with reduction of the apparent density. However, for densities below $150 \mathrm{~kg} / \mathrm{m}^{3}$, this diminishing relationship is not obvious (Chen 2014, Gilka-Bötzow 2010, Jiang 2016, Liu 2014).

Table 1: Dry density ranges and proposed categorization for porous cementitious foams with aggregates $\mathrm{D}<2 \mathrm{~mm}$.

\begin{tabular}{|c|c|}
\hline dry density range $\left[\mathbf{k g} / \mathbf{m}^{\mathbf{3}}\right]$ & category \\
\hline $1400-1800$ & (reinforced) foam concrete \\
\hline $800-1400$ & foam mortar \\
\hline $400-800$ & mineralized foam \\
\hline $400-160$ & (very) lightweight mineralized foam \\
\hline$<160$ & ultra-lightweight mineralized foam \\
\hline
\end{tabular}

The present study aims at developing and researching an ULMF - which is stable in the fluid and hardened state. To realize such an ULMF with a density of $100 \mathrm{~kg} / \mathrm{m}^{3}$, an air void content over $95 \%$ has to be reached by adding large amounts of prefabricated foaming agent (Gilka-Bötzow et al. 2016). Coalescence and fragmentation of bubbles in fresh foam concrete is unavoidable due to thermodynamic instability in the foam. This phenomenon usually leads to collapse of the foam concrete during the hardening process, which in turn leads to an increase in density and a deterioration in physical properties (Tscheuschner 1999, Mathes 2004). Studying the stability of the aqueous foams is useful to understand the mechanism that leads to collapse and to improve the stability of ULMF. Moreover, the cement slurry as the so called continuous phase of a fresh cementitious foam, plays also an essential role. If the slurry has poor rheological properties, the fresh cementitious foam will desintegrate while mixing or during the hardening process (Gilka-Bötzow \& Koenders 2015). The rheological behaviour of concretes may typically be changed by adding superplasticizer and/or by altering the water content. A good understanding the effect of these parameters on the stability of fresh and hardened mixtures is critical for preparation of a stable ULMF. 


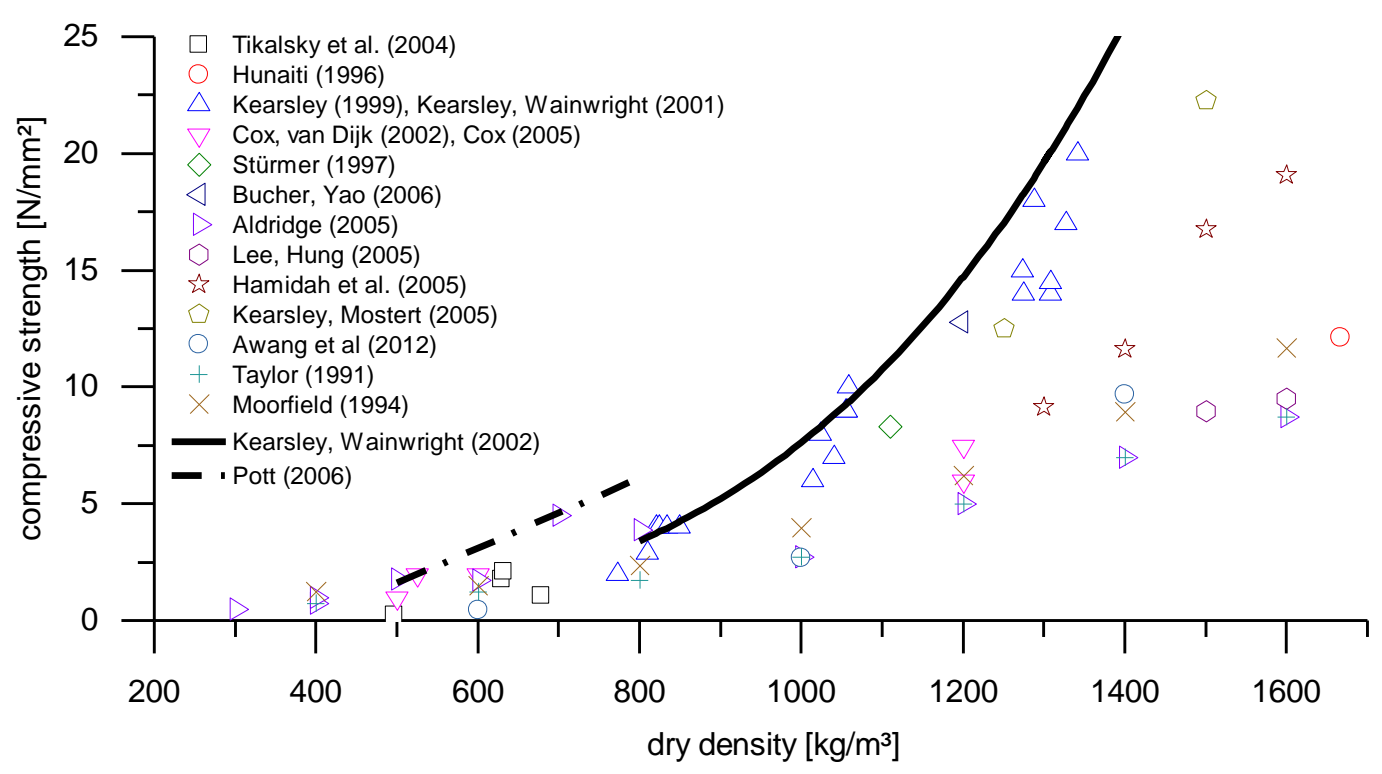

Figure 1: Relationship between 28 days compressive strength and bulk density of "foamed concrete" being the result of a meta-study.

In the present study, for creating a stable ULMF with densities below $100 \mathrm{~kg} / \mathrm{m}^{3}$, aqueous foam stability was researched by comparing six foaming agents with the same density $\left(80 \mathrm{~kg} / \mathrm{m}^{3}\right)$ over time. The effect of different aqueous foam densities $\left(60 \mathrm{~kg} / \mathrm{m}^{3}\right.$ and $80 \mathrm{~kg} / \mathrm{m}^{3}$ ) on the properties of hardened cementitious foams were determined. ULMF was prepared using Portland cement, silica fume, lime-stone flour and several chemical admixtures. The thermal conductivity, density, porosity and compressive strength of the hardened ULMF at age of 28 day were tested.

\section{MATERIALS AND METHODS}

\section{Raw Materials}

Materials used for this research included OPC (CEM I 52.5 N, Leimen plant, Germany), silica fume, lime-stone flour with a particle size from $0 \mu \mathrm{m}$ to $20 \mu \mathrm{m}$. Besides, hardening accelerator (formiat) and shrinkage reducing agent (calciumsulfoaluminat) were added to the cement slurry. In addition, six foaming agents were used to compare the foam stability over time. Three of them are based on synthetic surface active substances (denoted $\mathrm{S}_{1}, \mathrm{~S}_{2}, \mathrm{~S}_{3}$ ), two are protein-based (denoted $\mathrm{P}_{1}, \mathrm{P}_{2}$ ) and one of them is a so called biotenside (denoted $\mathrm{B}_{1}$ ).

\section{Mix Design}

The mix design was done using a rational mix design method (Gilka-Bötzow et al. 2016). The composition of the ULMF is reported in Table 2. Two densities of aqueous foams $\left(60 \mathrm{~kg} / \mathrm{m}^{3}\right.$ and $\left.80 \mathrm{~kg} / \mathrm{m}^{3}\right)$ were prepared by using a pre-foaming method. A PCEsuperplasticiser was used to enhance the workability of the cement slurry and to reduce 
water consumption. The superplasticiser had a low content of defoaming agent. It had also a slight retarding effect, as nearly all foaming agents have.

Table 2: Mix design

\begin{tabular}{|c|c|c|c|c|c|c|c|c|c|}
\hline 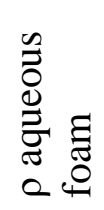 & $\begin{array}{l}\overrightarrow{0} \\
\text { है }\end{array}$ & $\begin{array}{l}\frac{\bar{d}}{\tilde{J}} \\
\overline{3}\end{array}$ & 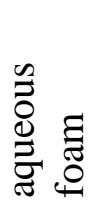 & 巳ు & $\begin{array}{l}\underset{\Xi}{\Xi} \\
\stackrel{\Xi}{\Xi} \\
:=\end{array}$ & 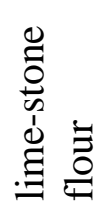 & 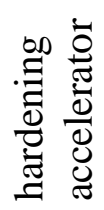 & 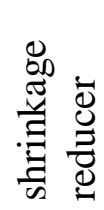 & $\frac{4}{3}$ \\
\hline \multicolumn{9}{|c|}{$\mathrm{kg} / \mathrm{m}^{3}$} & \\
\hline 60 & \multirow{2}{*}{58} & \multirow{2}{*}{23.9} & 57 & \multirow{2}{*}{0.3} & \multirow{2}{*}{5.8} & \multirow{2}{*}{5.8} & \multirow{2}{*}{1.2} & \multirow{2}{*}{2.9} & \multirow{2}{*}{0.33} \\
\hline 80 & & & 76 & & & & & & \\
\hline
\end{tabular}

\section{Production Procedure}

The foam concretes were prepared according to the proportions listed in table 2, at 20 ${ }^{\circ} \mathrm{C}$. The process is specified as follows: Firstly, water with superplasticiser was poured into a colloidal mixer, and then the half amount of Portland cement and additives were added gradually. After stirring for $90 \mathrm{~s}$, the other half of cement and additives were poured into the colloidal mixer followed by another $90 \mathrm{~s}$ stirring. The aqueous foam was produced using a foam generator to the aimed density. The generator is equipped with a proportional mixer to add a fixed amount of foaming agent $(2 \%)$ to the water. Compressed air then flows into the fluid. With this, the kinetic energy is converted into surface energy. The so generated foam was then thoroughly mixed with the base mixture. The demoulding process was conducted after 14 days, then samples were fully covered with polyethylene film and cured at $20^{\circ} \mathrm{C}$ until 28 days. After that all specimens were oven dried at $45^{\circ} \mathrm{C}$ until constant weight was achieved.

\section{Experimental Tests}

To determine the velocity of foam decay, bulk aqueous foams were filled in flat bottom glasses with a height of $120 \mathrm{~mm}$ and a diameter of $60 \mathrm{~mm}$. After that the foam height was recorded every $30 \mathrm{~min}$ from the beginning up to $120 \mathrm{~min}$. Based on this, the decay rate was calculated as the quotient of the measured height and the initial height. The thermal conductivity was measured using prismatic standard cement test samples $(160 \mathrm{~mm} \cdot 40 \mathrm{~mm} \cdot 40 \mathrm{~mm})$ by the transient plane heat source method according to the EN ISO 22007-2. The compressive strength test was conducted with the cubic samples $(15 \mathrm{~mm} \cdot 150 \mathrm{~mm} \cdot 150 \mathrm{~mm})$ according to the EN 12390-3. In order to be able to observe the entire failure process of the mineralized foam, the compressive test was continued up to a compaction of more than $50 \%$. The loading rate was set to $0.2 \mathrm{MPa} / \mathrm{s}$. The thermal conductivity as the compressive strength of the foam concrete were calculated as the average value of three parallel specimens. The total porosity was calculated from the skeletal density determined by a helium pycnometer and the bulk density calculated by dividing volume of sample by its mass. 


\section{RESULTS AND DISCUSSION}

\section{Aqueous foam}

Figure 2 shows the decay of the tested aqueous foams after $120 \mathrm{~min}$. Although all foams had the same density $\left(80 \mathrm{~kg} / \mathrm{m}^{3}\right)$, the protein-based foams $\left(\mathrm{P}_{1}, \mathrm{P}_{2}\right)$ show a more closed air void structure that allows to contain a greater amount of small air voids. This also guarantees a more stable foam network. In contrast, the synthetic foaming agents induced coarser air pores $\left(S_{1}, S_{2}, S_{3}\right)$. However, the aqueous foam produced with the biotenside foaming agent $\left(\mathrm{B}_{1}\right)$ collapsed rapidly from the top downward.
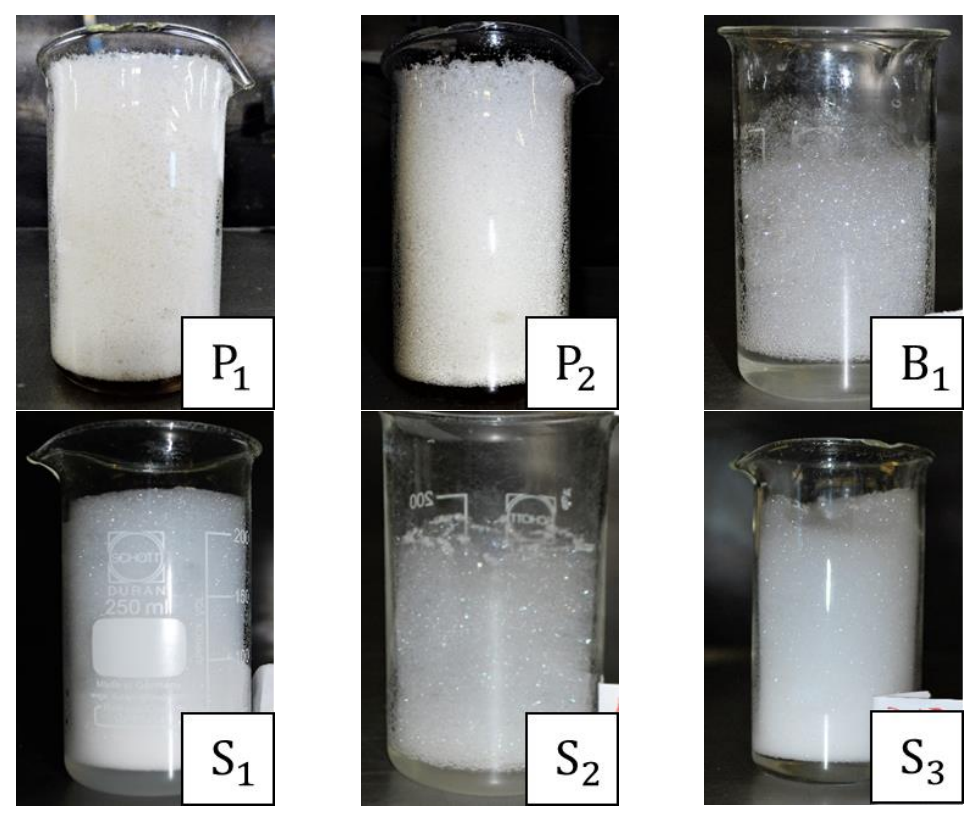

Figure 2: Decay of aqueous foams after $120 \mathrm{~min}$

Figure 3 shows the decay rate over time of the various aqueous foams based on the different foaming agents. The decay rate of the aqueous foams with different densities produced with $\mathrm{P}_{1}$ is shown in Figure 4 . When exposed to gravity, the aqueous foam structure changes from circular foams to hexagonal lattices. The curvature at these boundaries create a low pressure zone which results in compression between adjacent bubbles, while further accelerating drainage and reducing the distance between the adjacent membranes. The underlying aqueous foams gradually shrunk until they disappeared, and the upper aqueous foams gradually enlarged, while the membranes between the aqueous foams became thinner (Bikerman 1973). As can be seen in the Figure 2 and Figure 3 the collapse of the aqueous foam was accompanied by an increase in water volume. From the Figure 4 it is apparent that the aqueous foam with low density $\left(50 \mathrm{~kg} / \mathrm{m}^{3}\right)$ collapsed much more obvious and faster than the high density foam $\left(80 \mathrm{~kg} / \mathrm{m}^{3}\right)$. This provides a guidance on the choice of an aqueous foam with an appropriate density for the mineralizing process. 


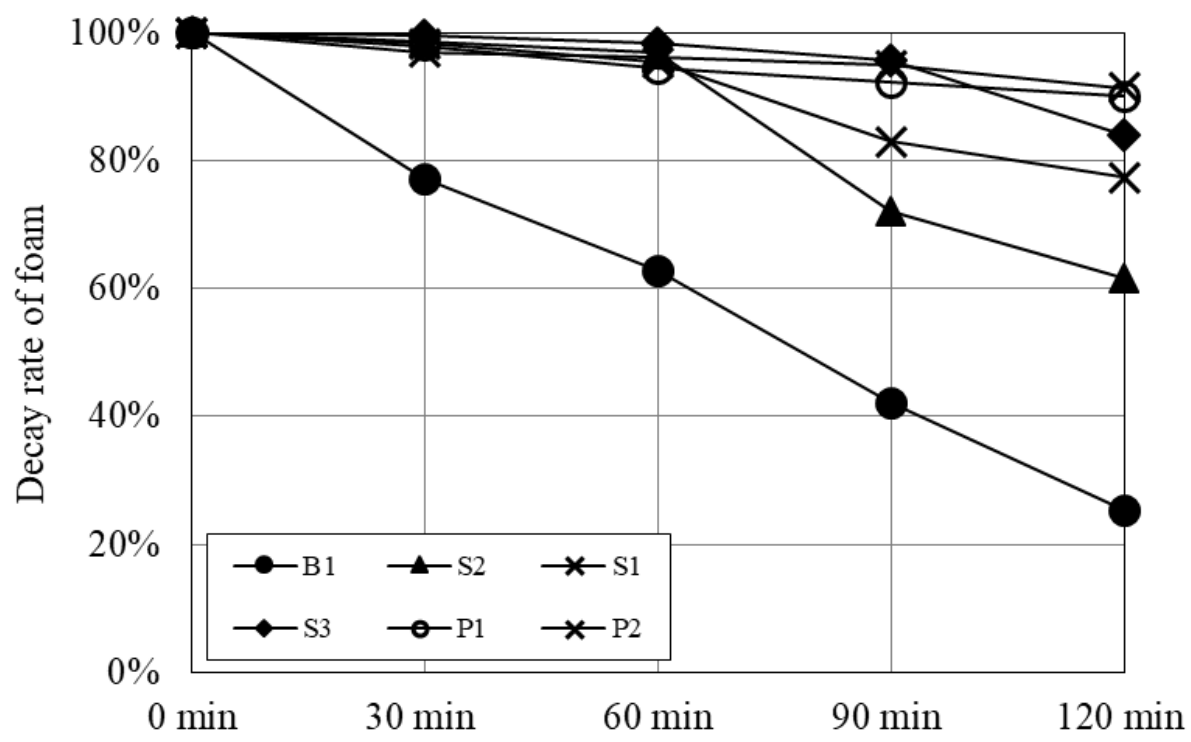

Figure 3: Decay rate of aqueous foams based on the different foaming agents.

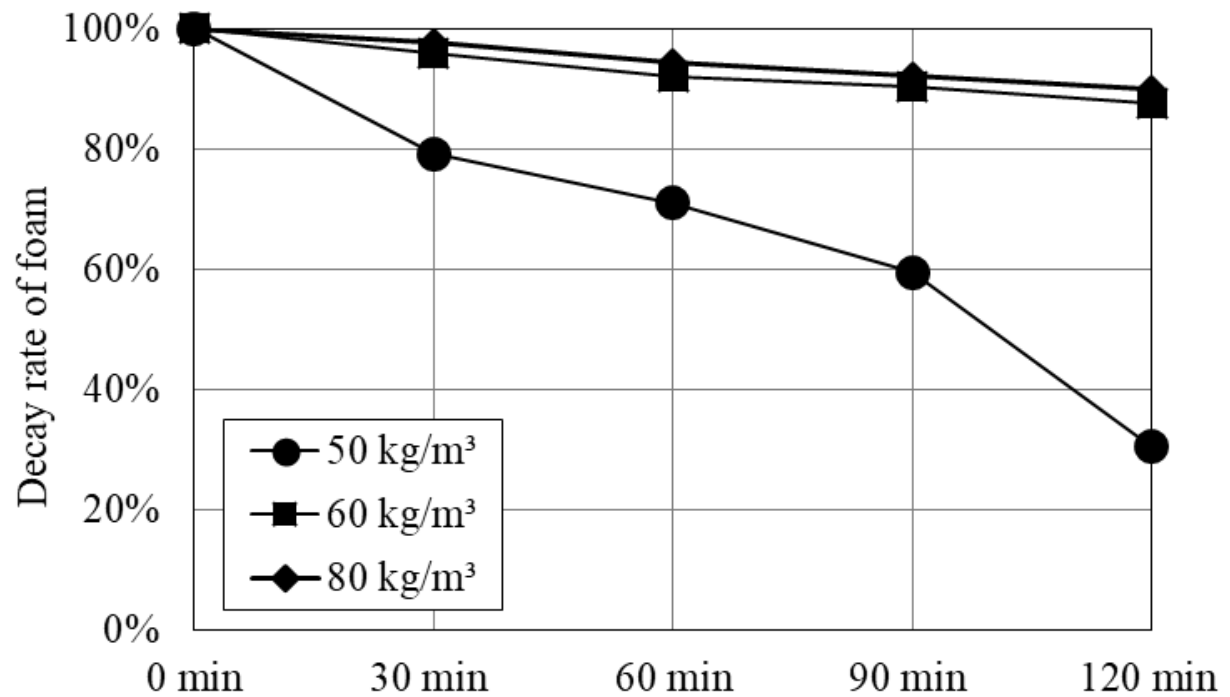

Figure 4: Decay of aqueous foams $\left(\mathrm{P}_{1}\right)$.

\section{Mineralized Foam}

Figure 5 shows the representative stress-strain curves of the tested ULMFs with the aqueous foam density $60 \mathrm{~kg} / \mathrm{m}^{3}$ and $80 \mathrm{~kg} / \mathrm{m}^{3}$, respectively. Figure 6 shows in more detail the same curves near the coordinate origin. All the stress-strain curves of the ULMFs demonstrated similar trends regardless of the aqueous foam density. First the foam bubbles on the surfaces collapsed under the applied load, later the inner structure of the foam broke as a second failure mechanism. The curve for the compression process can be roughly divided into four stages:

Stage I (o-a, strain approx. $0 \%-3 \%)$ : First the strain increases rapidly with the stress (elastic platform). This trend can be traced back to the collapse and compaction of the 
surface voids, which often have poor mechanical properties. For that there are several complementary reasons. First the pores on the surface are not closed, but kind of hemispheric open pores. Therefore, the surface of the sample has for geometrical reasons a lower bearing capacity. Moreover on the one hand there is too much water on the underside of the specimen due to the drainage of the aqueous foam. On the other hand later there is always too little water near the surface during hydration due to superficial drying, which causes a gradient of humidity inside the open pore structure of the material. The pore structure gets gradually compacted with the increasing stress. Stage II (a-b strain approx. $3 \%-15 \%$ ): The strain continues to increase almost linear with the stress but at a lower rate than stage I.

Stage III (b-c strain approx. $15 \%-70 \%$ ): The strain increases with a wavering stress. At this stage, the stress reaches its maximum. This stage is characterized by a continuous collapse of the air-void structure within the sample.

Stage IV (c-d strain approx. $70 \%$ ): The stress begins to decrease. During this process, the residual strength of ULFM tends to be constant while the strain increases slightly until reaching a plateau.

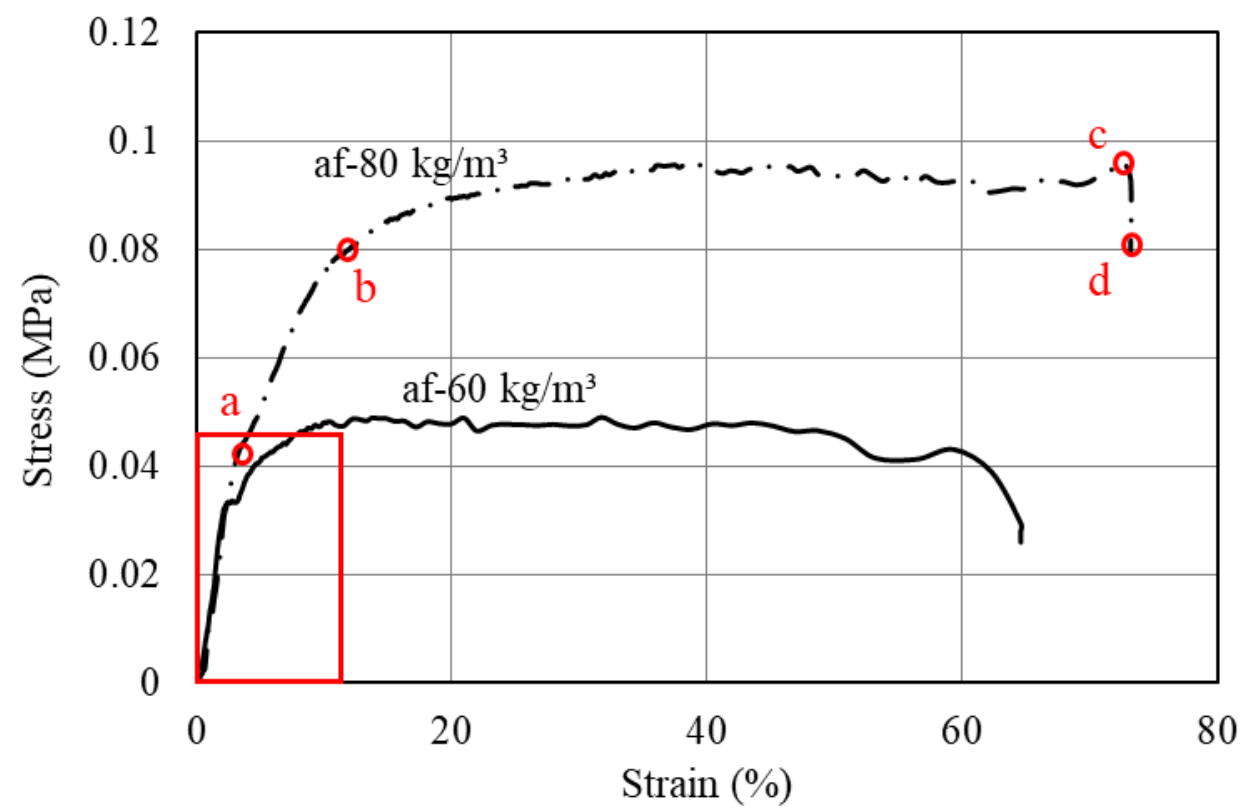

Figure 5: Strain-stress diagrams of the tested ULMFs with different densities.

Figure 6 shows the same curves as before up to $10 \%$ strain, with stage I and II respectively being fitted by a straight line. According to experimental observations and abovementioned analysis, when the stress reaches the intersection $\sigma_{1}$ and $\sigma_{2}$, the broken pores were further compacted forming a layer of dense concrete powder. At this point, it can be considered that the maximum compressive strength has been reached. 


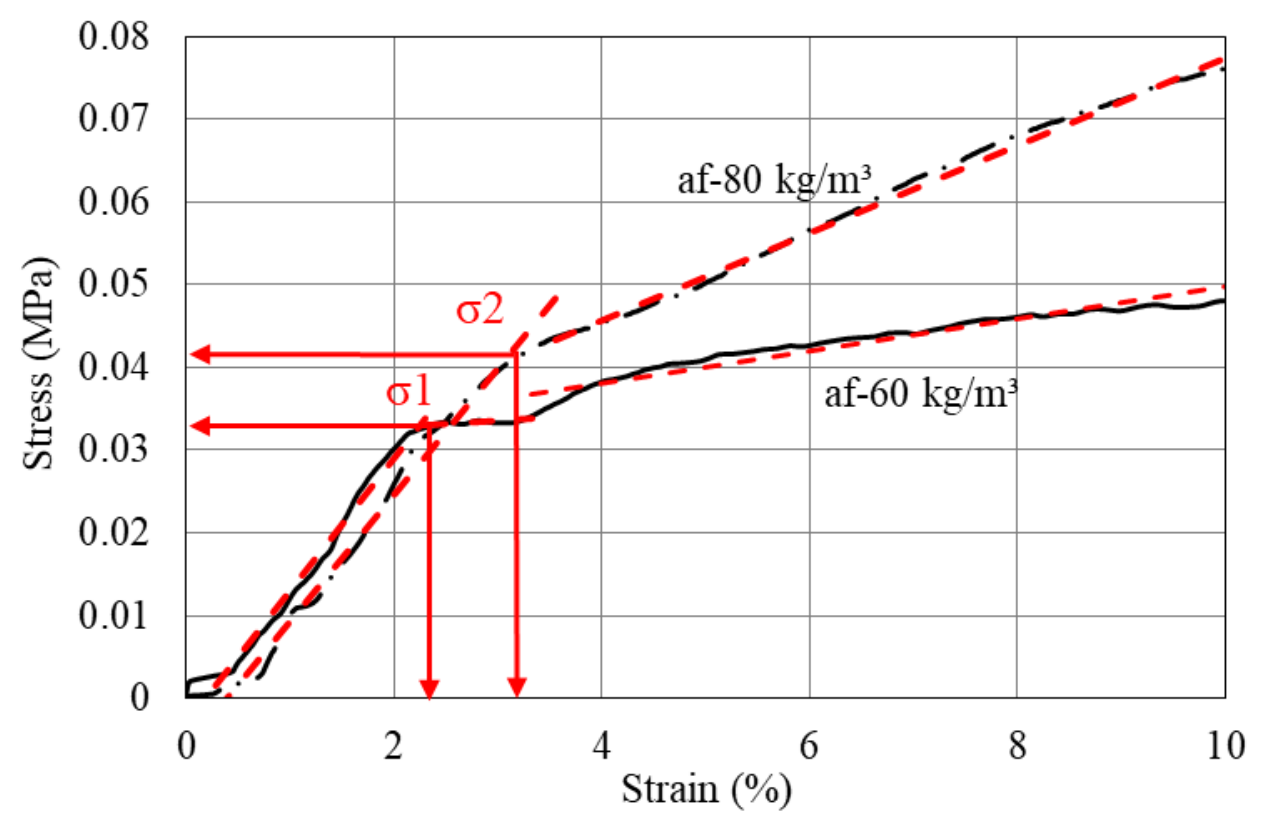

Figure 6: Detail of the strain-stress relation of the tested ULMFs with different densities.

Besides the compressive strength, the different aqueous foam densities have a considerable effect on other physical properties of the ULMFs as shown in Error! Reference source not found.. It is apparent that a low aqueous foam density results in a lower compressive strength and also in a slightly lower dry apparent density of the ULMF. In addition, it has a significant effect on thermal conductivity. All these phenomena are most probably due to the respective pore structures that are formed. Depending on the bulk density of the aqueous foam used, the porosity differs in pore size distribution, but also in the type of the formed pore walls. These can have different thicknesses and tightness.

Table 3: Experimentally determined physical properties of the mineralized foams investigated

\begin{tabular}{|c|c|c|c|c|}
\hline $\begin{array}{c}\text { aqueous foam } \\
\text { density }\end{array}$ & $\begin{array}{c}\text { compressive } \\
\text { strength }\end{array}$ & $\begin{array}{c}\text { thermal } \\
\text { conductivity }\end{array}$ & $\begin{array}{c}\text { dry apparent } \\
\text { density }\end{array}$ & total porosity \\
\hline$\left[\mathrm{kg} / \mathrm{m}^{3}\right]$ & {$[\mathrm{MPa}]$} & {$[\mathrm{W} /(\mathrm{m} \cdot \mathrm{K})]$} & {$\left[\mathrm{kg} / \mathrm{m}^{3}\right]$} & {$[\%]$} \\
\hline 60 & 0.030 & 0.048 & 97.2 & 96.6 \\
\hline 80 & 0.041 & 0.053 & 98.3 & 96.4 \\
\hline
\end{tabular}

However, there is no obvious difference in the total porosity between them. It indicates that the water content of the aqueous foam in the present case has no major influence on the total porosity which includes also the porosity of the solid material framework. With this, the mentioned water amount is directly proportional to the created apparent porosity and so indirectly proportional to the density of the mineralized foam. For these reasons, together with the real water cement ratio, the amount of water in the aqueous foam, relative to the total water content, rises disproportionally with declining densities (Gilka-Bötzow et al. 2016). So, not by considering the water in the aqueous 
foam in the mix design, as is reported in many publications (e. g. Narayanan \& Ramamurthy, 2000), which is normally only acceptable for higher dry densities.

\section{CONCLUSION}

The present study aims at developing an ultra-light mineral foam (ULMF) as a thermal insulation material to reduce the energy consumption of buildings and to enable a sustainable product. A robust ULMF with a dry density of about $100 \mathrm{~kg} / \mathrm{m}^{3}$ and an air void content of $98 \%$ was developed, which showed a 28 day compressive strength around $0.04 \mathrm{MPa}$ and a thermal conductivity of about $0.053 \mathrm{~W} /(\mathrm{m} \cdot \mathrm{K})$. The stability of aqueous foams was researched by comparison of different foaming agents over time. Protein-based foaming agent, in general, can create a highly stable foam with a closed cell structure, which provides a more stable network of air voids than synthetic foaming agents. Moreover, the density of aqueous foam affects its stability, thereby affecting the properties of ULMF. The increase of density of aqueous foams (from 60 $\mathrm{kg} / \mathrm{m}^{3}$ to $80 \mathrm{~kg} / \mathrm{m}^{3}$ ) has a larger influence on the increase of the compressive strength $(40 \%)$ than on the thermal conductivity $(10 \%)$ of ULMFs. In extended tests on the compressive strength of the mineralized foams the total failure mechanism was investigated and classified in four stages. More knowledge about this behaviour can be useful in the context of understanding the energy-dissipating behaviour of these materials.

\section{ACKNOWLEDGEMENTS}

The authors would like to thank the laboratory staff of the Institute for Construction and Building Materials of the TU Darmstadt. The authors also acknowledge firma Röser Ingenieurbeton, Neresheim (Germany), for the generous support of this study.

\section{REFERENCES}

Akthar, F. K., Evans, J. R. G. (2010). "High porosity (> 90\%) cementitious foams." Cem. Concr. Res., 40(2), 352-358.

Aldridge, D. (2005). "Introduction to foamed concrete: What, why and how? ", In Use of foamed concrete in construction (pp. 1-14). London, UK: Thomas Telford.

Awang, H., Mydin, M. A. O., Roslan, A. F. (2012). "Effect of additives on mechanical and thermal properties of lightweight foamed concrete." Pelagia Res. Libr, 3(5), 3326-3338.

Bikerman, J. (1973). Foams. New York: Springer-Verlag.

Bucher, A., Yao, Y. (2006). "Einfluss von Kunststofffasern auf die Eigenschaften von Schaumbeton" (Bachelorarbeit). ETH Zürich, Zürich.

Chen, X., Yan, Y., Liu, Y., Hu, Z. (2014). "Utilization of circulating fluidized bed fly ash for the preparation of foam concrete." Constr. Build. Mater., 54, 137-146.

Cox, L., van Deijk, S. (2002). Foam concrete. Concrete, 25(5), 54-55. 
Gilka-Bötzow, A. (2010). "Mineralisierter Schaum.", In W. Breit, W. Kurz, \& C. Schnell (Eds.), Beiträge zum 51. DAfStb Forschungskolloquium (Vol. 2, pp. 709-720). Kaiserlautern.

Gilka-Bötzow, A. (2017). "Stabilität von ultraleichten Schaumbetonen: Betrachtung instationärer Porenstrukturen." Springer-Verlag.

Gilka-Bötzow, A., Koenders, E. A. B. (2015). "Rheological behavior of the continuous phase of foams and its effect on the dispersed phase." In Proceedings of 24. Workshop und Kolloquium Rheologische Messungen an Baustoffen. Regensburg.

Gilka-Bötzow, A., Zimmer, M., Koenders, E. A. B. (2016). "Material Properties of mineralized foam and its density dependency - a meta-study." In Proceedings of the int. Conf. on Concrete Sustainability (ICCS16). Madrid.

Hamidah, M., et.al. (2005). "Optimisation of foamed concrete mix of different sandcement ratio and curing conditions." In Use of foamed concrete in construction. Thomas Telford: London, UK, 37-44.

Hunaiti, Y. M. (1996). "Composite Action of Foamed and Lightweight Aggregate Concrete." Mater. in Civ. Engi., 8(3), 111-113.

Jiang, J., et. al. (2016). "Study on the preparation and properties of high-porosity foamed concretes based on ordinary Portland cement." Mater. Desi., 92, 949959.

Kearsley, E. P., Mostert, H. F. (2005). "Opportunities For Expanding The Use Of Foamed Concrete In The Construction Industry." In Use of foamed concrete in construction, Thomas Telford: London, UK, 144-145.

Kearsley, E. P., Wainwright, P. J. (2001). "The effect of high fly ash content on the compressive strength of foamed concrete." Cement and Concrete Research, 31(1), 105-112.

Kearsley, E. P., Wainwright, P. J. (2002). "Ash content for optimum strength of foamed concrete." Cement and Concrete Research, 32(2), 241-246.

Kearsley, E., Mostert, H. (2005). "Designing mix composition of foamed concrete with high fly ash contents." In Use of foamed concrete in construction. London, Thomas Telford, 29-36.

Kearsley, E. (1999). "The effect of high volumes of ungraded fly ash on the properties of foamed concrete" (Dissertation). University of Leeds, Leeds.

Lee, Y., Hung, Y. (2005). "Exploitation of Solid Wastes in Foamed ConcreteChallenges Ahead." In Proceedings of International Concrete Congress (pp. 15-22).

Liu, M. Y. J., Alengaram, U. J., Jumaat, M. Z., Mo, K. H. (2014). "Evaluation of thermal conductivity, mechanical and transport properties of lightweight aggregate foamed geopolymer concrete." Ener. Buil., 72, 238-245.

Mathes, H. (2004). "Monodisperse Schäume: Herstellung und Verwendung als strukturiertes Medium für chemische Zweiphasenreaktionen" (Dissertation).

Moorfield, G. (1994). "Filling a gap in the market." Concrete, 28(3), 12-14.

Narayanan, N., Ramamurthy, K. (2000): Structure and properties of aerated concrete: a review. In: Cement and Concrete Composites 22, 321-329 
Narayanan, J. S., Ramamurthy, K. (2012). "Identification of set-accelerator for enhancing the productivity of foam concrete block manufacture." Constr. Build. Mater., 37, 144-152.

Othuman, M. A., Wang, Y. C. (2011). "Elevated-temperature thermal properties of lightweight foamed concrete." Constr. Build. Mater., 25(2), 705-716.

Panesar, D. K. (2013). "Cellular concrete properties and the effect of synthetic and protein foaming agents." Constr. Build. Mater., 44, 575-584.

Pott, J. U. (2006). "Entwicklungsstrategien für zementgebundene Schäume (Dissertation)." Universität Hannover.

Ramamurthy, K., Nambiar, E. K., Ranjani, G. I. S. (2009). "A classification of studies on properties of foam concrete." Cem. Concr. Com., 31(6), 388-396.

Ranjani, G. I. S., Ramamurthy, K. (2012). "Behaviour of foam concrete under sulphate environments." Cem. Concr. Com., 34(7), 825-834.

Stürmer, S. (1997). "Injektionsschaummörtel für die Sanierung historischen Mauerwerks unter besonderer Berücksichtigung bauschädlicher Salze" (Dissertation). Bauhaus-Universität Weimar, Weimar.

Taylor, R. (1991). "Foamed Concrete: Composition and Properties." Crowthorne: British Cement Association.

Tikalsky, P. J., Pospisil, J., MacDonald, W. (2004). "A method for assessment of the freeze-thaw resistance of preformed foam cellular concrete." Cement and Concrete Research, 34(5), 889-893.

Tscheuschner, H. D. (1999). "Grundzüge der Lebensmitteltechnik", Studienausg., 2., neubearb. Aufl., Nachdr., Hamburg: Behr. 